\title{
BHARATHI MUKHERJEE - THE VOICE OF CONTEMPORARY AMERICAN IMMIGRANT \& EXPATRIATE SOCIAL REALITY
}

\section{P Rajeswari}

Research Scholar

Bharathiyar University

Tamil Nadu
Dr K Balamurugan

Professor of English

Bharathiyar College of Engg \& Tech

Pondicherry U T

\section{ABSTRACT}

Bharathi Mukherjee is an American writer of Indian origin. Her fictional masterpieces deal almost exclusively and obsessively with the problems faced by the South Asian immigrant Women, especially India women immigrants. In her novels and short stories, she realistically paints the contemporary American immigrant and expatriate social reality. Unlike other feminist writers, Bharathi Mukherjee's feministic concerns primarily deals with the sphere of cross-cultural conflicts, acculturation, assimilation and other related issues of the new woman immigrants like nostalgia, isolation and rootlessness. Her women protagonists are exiles, immigrants or expatriates who come from India to live in America for various reasons. Their endless psycho-sociological struggles are captured by Bharathi Mukherjee with feminine empathy and objectivity using a refined language and style.

KEYWORDS: Bharathi Mukherjee, South Asian immigrant, Women, India women immigrants, social reality, cross-cultural conflicts, acculturation, assimilation, nostalgia, isolation, rootlessness

\section{INTRODUCTION:}

Bharathi Mukherjee has gained critical literary recognition as a prominent writer in Asian American literature and Canadian multicultural literature and expatriate Indian Women Writers in English, Indian diasporic literature in a very short period. Today she is considered to be one of the most popular contemporary immigrant or expatriate writers living in America. Using her inimitable style and intense firsthand experiences, she vividly describes the predicament of Indian women immigrants in the new world where cultures confluence in to a modern way of life filled with chaos and violence. For immigrant women, life in the new world means endless rebirths and redefinitions in thoughts, identities, personalities, cultures, attitudes and world view. Bharathi Mukherjee's novels brilliantly portray the trauma of immigrant women psyche in all its natural colours and minute details in the process of cultural transformation or transfiguration. When the immigrant protagonists are violently immersed into a mix of diverse and unrelated cultures, they experience a sense of awe, confusion, nostalgia, rootlessness 
ELK

Asia Pacific Journals

and identity crisis. Because of her faithful portrayal of such an extremely complex experience of the process of immigration and the life of immigrant women, the works of Bharathi Mukherjee are considered today as one of the authentic chroniclers of contemporary immigrant life in America. Her sensational works originate from her own intense autobiographical experiences and concern themselves with the genuine cause of Indian women immigrants in America. That is why she is rightly considered as the "living voice of the contemporary American immigrant and expatriate social reality. A critical assessment of some of her compelling novels will bring out her immigrant sensibility and authentic concern for Asian/Indian women immigrants.

Bharathi Mukherjee's first novel The Tiger's daughter published in 1972 revolves around the life of Tara, an immigrant protagonist from India. She receives her higher education at Vassar College, New York. Like Bharathi Mukherjee, who visited India after her marriage with Clark Blaise in 1973, Tara gets back Calcutta after her ten year stay in America; she comes to India only to witness
ELK Asia Pacific Journals - Special Issue

ISBN: 978-81-930411-1-6

poverty and political chaos in India. This dispirits her culturally elevated, transfigured but homesick heart. The ill-treatment meted out to Indian women in the name of age old traditional practices shocks her. The old memories of her home land now starkly contrast with her stern present and create a perplexing inner distress. Unable to feel a sense of belonging in India and in America, Tara feels rootless. Consequently, her identity also suffers a serious crisis. The geographical dislocation creates a cultural duality and stratifies her subjective reality qualitatively. This is the reason why she is unable to feel herself at home in both of her worlds. The better of the two homes, America, makes cultural integration through acculturation difficult for her through its cultural plurality. Tara, the Indian born woman with her deeply embedded Indian culture and values finds Americanism to be a inevitable nightmare. Uprooted from her native culture and identity and have lost a sense of belonging, she lives the life of an exile. The tale of Tara and Tara herself are seen by most critics as the mental projections of Bharathi Mukherjee and her earlier experiences in Canada. Empowered by real life experiences and an admirable writing skill, the novelist expresses her 
ELK

Asia Pacific Journals

experiences cross cultures, cultural shock, alienation and angst that she lived through in her earlier stages. The title of the novel seems to suggest a longing reminiscence of her status as a daughter to a good and caring father.

Bharathi Mukherjee's second novel Wife (1975) is about a naive, intensely emotional and fragile woman protagonist, Dimple Mukherjee. Dimple is a simple and obedient Indian girl with an ingrained Indian culture and value system. She firmly believes marriage is a privilege and a blessing that will completely transform her life and bless her with unlimited freedom, great fortune and endless joy. So, she eagerly and restlessly waits for her arranged marriage with Amit. In the case of Dimple, the change takes place simultaneously in multiple planes, the personal, familial and cultural. As the name of the novel clearly signifies, Dimple is now a wife and no longer a Tiger's daughter. As a responsible daughterin-law, Dimple is expected to adapt to her second home. But Dimple finds her motherin-law and the new home disagreeable. Her dreams of a happy marriage are shattered and her ugly reality drags her back from her colourful fancies. She soon feels Amit was
ELK Asia Pacific Journals - Special Issue

ISBN: 978-81-930411-1-6

not the man she dreamed to marry. However, she becomes pregnant and is now a would-be mother. Motherhood is seen as a divine state by Indian women but Dimple sees it as a fettering punishment. She skips ropes and kills her own child even before it comes out to see the world. Surprisingly, she never regrets a bit as her mind rejects even the slightest pain and only prefers endless pleasures of this illusory world. When her husband gets his visa and moves to the US to get a job there, Dimple is delighted beyond words. Yet the big New York scares her and makes her hide in her gloomy apartment. Depression begins to possess Dimple and she begins to break inside. All the alien social negativity thrills Dimple and even drives her to act negatively. She kills Amit in a fit and also kills herself. Thus, we see a dreamy and uprooted girl in Dimple, who suffers because of her limitations and dies pitiably.

Dimple is Bharathi Mukherjee's Lady Macbeth. She is apparently stone hearted and dangerously delusional. Her problems are uniquely weaved within and across contrasting cultures and identity shifts. Her fancy becomes her enemy within. Her flaws are her inability to reconcile, adapt and 
ELK

Asia Pacific Journals

accept her own reality. Dimple is evidence for Bharathi Mukherjee's exceptional characterisation skills and will ever live in the pages of Diasporic Indian literature and speak the novelist's unspoken thoughts forever.

Bharathi Mukherjee fictional masterpiece Jasmine was published in 1989. Unlike Tara and Dimple, Jasmine is a highly resourceful, strong and has the ability and will to perfect her social and personal reality even at the face of daunting challenges for a woman like her. Jasmine is just like any other Indian girl. Unfortunately, she becomes a widow at the age of young age of seventeen when her husband is murdered. She comes to America to start afresh but is raped by a cheat. She burns the painful memory of it using her fiery will and moves ahead relentlessly. She assumes various names and positions and finally becomes a health professional, a healing angel in spite of her aching inner wounds. Jasmine is an epitome of modern Indian woman, who suffer endless trials in their lives and yet come out successful at last with sheer will and determination. Through Jasmine Bharathi Mukherjee shows that all cultural problems can be successfully faced and
ELK Asia Pacific Journals - Special Issue

ISBN: 978-81-930411-1-6

solved if the woman immigrants are strong at heart. This change directly corresponds to her own mindset after her painful experiences in the racist and provincial Canada.

Jasmine glorifies womanhood and hints at the enduring and limitless feminine strength which can overcome all hurdles and shower kindness and divine love at all men. Jasmine, the young widow, comes to America as a refugee but becomes stronger through her trials of cultural assimilation. Her emotional journey contrasts East and the West in terms of its treatment of women. In the process of becoming she gains and sheds many names and identities. She traverses through many worlds but endures through her will to push forward and succeed in life.

Leave it to me (1997) is the touching narrative of a Californian love-child born of a hippie and abandoned in an orphanage by her biological parents. The poor child is adopted by the kind and caring ItalianAmerican family and named as Debby Di Martino. Though she receives the warm love of her foster parents, Debbie feels like a fish out of water and is troubled. When her troubling reality overlays on her unknown inner identity, she becomes restless and 
ELK

Asia Pacific Journals

deeply troubled. She decides to find her true roots and her real parents. In her way, Debbie meets many mean men. Her journey provides her the answers. Yet the sense of rootlessness and loss haunts her and blurs her subjective identity. Thus, we see through Debbie that Bharathi Mukherjee own quest has now become less cross-cultural and more sociological and psychological.

Desirable Daughters (2003), tells the story of three Calcutta born daughters Tara, Padma and Parvathi who journey from one world to another with remarkably different cultures. The feminine trio are born rich and loving Brahmin father and conservative mother. The girls are clever and creative however, their society tries to lock them away. Their revolt makes to take untrodden paths to different places, trying circumstances that test them to their limits yet strengthens their feminine will to succeed. The trio in Desirable Daughters are immersed in to new cultures, take on new identities, and at the same time remain grateful to their loving family but still go against the conservative society. Bharathi Mukherjee now turns her gaze from America to India and focuses on the taboos in the Indian society that work against
ELK Asia Pacific Journals - Special Issue

ISBN: 978-81-930411-1-6

women and push them into misery in the name of sacred tradition and custom.

\section{Bharathi Mukherjee's The Tree Bride} (2004) presents the rich, sophisticated and cosmopolitan Tara Lata and her unforeseen calamity which pushes her to come back to her home land (India). Like Debby she searches for their historical Indian roots. It narrates how she becomes the tree bride when her would-be dies by a snake bite and her father marries her to the Forest God to save her. Tara, the widowed woman becomes a social worker. She embraces the poor and the homeless and participates in the India's freedom struggle. She is sentenced to death by the British. Mukherjee again delves in to the past of her home town. Calcutta and digs out its cruelty to young unfortunate widows, snobbery and connects it with British history. Tara Lata yearns for home and tradition, finds ancestral roots and her place in pre-independent India. She discovers the shameful past whence taboos like child marriage and superstition devastated the dreams and joy of young and innocent girls like Tara Lata. 
ELK

Asia Pacific Journals

Miss New India (2011) is the most recent novels Bharathi Mukherjee, which again has as its protagonist Anjali Bose, who finds herself in a dilemma of choices between a hapless marriage and a promising career. Encouraged by her teacher, Peter Champion, she takes her destiny in her hands and moves ahead from her gloomy backwater town to the Silicon Valley of the East and the great metropolitan city of Bangalore.

She finds herself in the company of young and highly ambitious youngsters, who speak the American slang to secure call centre jobs and earn a living. Anjali is now a high-tech city girl and has complete freedom. She overcomes her own past and recreates her present as she wishes. Once again, Bharathi Mukherjee records the struggle of an Indian girl, this time migrating within India from a small town to a big metropolis. The change of place demands a change of identity which Anjali readily makes and transforms her life.

\section{COMMENT}

Bharathi Mukherjee novels as we have seen show her genuine concern of women especially Indian women who are exiles, immigrants or simply migrants. It speaks volumes about their struggles and appeals
ELK Asia Pacific Journals - Special Issue

ISBN: 978-81-930411-1-6

for a social and cultural reform in the present world, where women are treated like dirt. The quick and widespread popularity of the novelist shows that her voices of concern and care have not gone unheeded.

\section{REFERENCES}

[1] Anita Myles. Feminism and the PostModern Indian Women Novelists in English. New Delhi: Sarup \& Sons, 2006.

[2] Somdatta Mandal. Bharathi Mukherjee Critical Perspectives. New Delhi: Pencraft Books, 2010.

[3] Nagendra Kumar. The Fiction of Bharathi Mukherjee - A Cultural Perspective. Chennai: Atlantic Publishers \& Distributors (P) Ltd., 2013.

[4] Sushma Tandon. Bharathi Mukherjee's Fiction - A Perspective. New Delhi: Sarup \& Sons, 2004. 